\title{
建筑工程技术管理的问题导向与提升
}

\author{
徐武 1 雷雪芳 2
}

1 浙江明康工程咨询有限公司 2 浙江明康工程咨询有限公司余杭分公司

DOI:10.32629/btr.v2i12.2736

[ 摘 要] 房屋工程技术管理主要是通过对施工中各项技术活动要素进行系统化管理,并利用管理的职能与科学的方法来保证建筑施工技术工 作顺利地、科学地、有秩序地开展, 所以说房屋工程技术管理是实现施工项目控制目标的必要手段, 同时还是保证工程施工进度、质量安全、成 本节约的重要措施。

[关键词] 房屋建筑; 工程技术; 管理

\section{1 房屋建筑施工技术管理水平的提升在建筑行业中的必要性}

建筑工程施工的整体水平在整体建筑工程中除了处在一个至关重要 的位置外, 同样也是建筑工程中一个必不可少的重要组成环节。通常情况 下, 建筑工程的质量是否合格是受到建筑工程的水平影响, 而建筑工程的 水平则取决于相应的施工技术。因此施工技术在整体的建筑工程中是起到 重大作用以及意义的, 所以需要对施工技术的管理水平不断进行提升, 使 得施工技术管理能够对施工技术起到相应的有效管理措施。建筑工程中施 工存在着诸多特点, 如环境复杂、规模庞大、涉及内容繁多以及相应投入 资源资金更多等。在此条件下, 使得建筑工程施工对施工技术的需求越来 越高, 因此需要更高的技术管理水平来进行保障, 确保整体建筑工程的综 合竞争力能够在市场中取得优势

\section{2 浅析房屋建筑工程技术管理存在的问题点}

2. 1 管理人员素质较低。我国的建筑企业队伍素质整体较低, 并且结构 层次也不尽合理。首先, 高等教育以上的以上学历人员不多, 从业人员的整 体教育水平较低。其次, 存在着重工程技术人员, 轻管理专业人员的倾向。 在缺少高素质的工程技术人员的同时, 合格的项目经理等企业经营管理方 面的人员更为缺少。

2. 2 管理观念落后。对于我国以往的房屋建筑工程来讲, 工程技术管理 一直采用的是旧的管理模式, 缺乏实效性和科学性。这种旧的管理模式, 没有根据施工原则而进行盲目的管理, 其管理手段并不科学, 只是采用硬 性的管理达到预期的目标。在管理中, 常常出现对建筑材料浪费的现象, 从而也增加了投资成本。

2. 3管理组织贯乏。管理方式太过集权, 缺乏实践操作的管理, 管理结 构不科学。因为房屋建筑生产的灵活性比较强, 管理结构的不科学会给建 筑生产带来局限性, 使其不能得到充分的发展。

\section{3 提出房屋建筑工程技术管理的有效举措}

3. 1 构建完善的建筑工程技术管理体系。一个完善的建筑工程技术管 理体系可以保障整个工程的技术管理工作顺利开展。要建立起以项目管理 部为主导, 各级技术管理机构权责清晰的建筑工程技术管理体系。要切实 考虑各级组织机构的专业层次和实际能力, 保障整个工程技术管理体系的 科学运作。施工技术管理工作要做到专人负责, 将职权落实到每一位技术管 理人员。在整个施工过程中, 都要格外重视技术管理工作人员的调度。同时 也要重视技术管理体系的监督工作, 在施工的各个环节做到全程监督, 提
高工程完成质量。企业应当正确认识到监管工作的重要性, 作为监管人员 也要提升个人专业素质, 严格执行监督工作, 以构建一个合理完善的建筑 工程技术管理体系, 从而保障施工的顺利进行。

3.2 重视技术管理人才的引进与培养。一个工程完成的好坏情况, 技术 管理人员起着决定性作用。企业应当重视技术人才的引进, 聘用符合企业 技术管理要求的人才。可以通过与大学实行校企合作办学的形式培养适合 自身企业的技术管理人才。当今社会科学技术不断发展, 建筑行业所运用 的高新科技成果也日新月异, 企业由于不断引进的新型建筑材料与新的施 工技术, 对于已经引进的技术管理人员也要加强其日常的培训工作, 不断 提升其专业水平和工作实践能力, 从而更好地运用到工作实践中。

3. 3坚持技术管理模式的创新。科学技术日新月异, 同科技紧密相关的 建筑工程技术管理也要随着时代的发展不断创新, 这才能够在激烈的建筑 行业市场竞争中立于不败之地。企业可通过定期开办员工技术管理研讨会 的形式, 为企业的技术管理模式献言献策, 从而激发员工技术管理创新能 力, 调动其工作积极性。

\section{4 结束语}

随着我国市场经济的迅速发展, 建筑行业的不断发展, 房屋建筑工程 技术管理在建筑工程中的作用越来越重要。建筑工程施工房屋建筑管理工 作的开展, 对于建筑工程的整体水平以及质量有着明显的提升。为了进一 步发挥房屋建筑管理的积极作用, 本文在明确房屋建筑管理重要性的基础 上, 以问题为导向, 积极进行房屋施工管理体系的创新, 实现对建筑工程施 工质量、施工技术等全方位管理, 形成现代完备的建筑工程施工房屋建筑 管理方案。因此, 我们要通过对工程技术管理的创新, 不断完善企业的管理 体制, 从而为企业创造更大的利益。

\section{[参考文献]}

[1]张立新.房屋建筑工程施工现场的技术管理措施与对策 [J].四川水 泥,2018,(10):177.

[2]温钦成.绿色节能施工技术在房屋建筑工程中的应用 [J].智能城 市,2018,4(14):96-97.

[3]张克楠,李翠莲.如何有效提升建筑工程施工技术管理水平 [J].建材 与装饰,2018,(27):158-159.

[4]薛冰.提升建筑工程施工技术管理水平的策略 [J].现代物业 (中旬 刊),2018,(11):63. 